\title{
High frequency stimulation-induced plasticity in the prelimbic cortex of rats emerges during adolescent development and is associated with an increase in dopamine receptor function
}

\author{
Shuo Kang ${ }^{1}$, Charles L. Cox ${ }^{1,2,3,6}$, and Joshua M. Gulley ${ }^{1,4,5}$ \\ ${ }^{1}$ Neuroscience Program, University of Illinois, Urbana-Champaign \\ ${ }^{2}$ Department of Molecular and Integrative Physiology, University of Illinois, Urbana-Champaign \\ ${ }^{3}$ Department of Pharmacology, University of Illinois, Urbana-Champaign \\ ${ }^{4}$ Department of Psychology, University of Illinois, Urbana-Champaign \\ ${ }^{5}$ Institute for Genomic, Biology, University of Illinois, Urbana-Champaign \\ ${ }^{6}$ Beckman Institute for Advanced Science, University of Illinois, Urbana-Champaign
}

\section{Abstract}

Recent studies in rats suggest that high frequency stimulation (HFS) in the ventral hippocampus induces long-term depression (LTD) in the deep layer of the medial prefrontal cortex (mPFC), but only after the prefrontal GABA system has sufficiently developed during early- to midadolescence. It is not clear whether this LTD is specific to the hippocampus-mPFC circuit or is instead an intrinsitc regulatory mechanism for the developed mPFC neuro-network. The potential mechanisms underlying this HFS-induced LTD are also largely unknown. In the current study, naïve male Sprague Dawley rats were sacrificed during peri-adolescence or young adulthood for in vitro extracellular recording to determine if HFS delivered in the prelimbic cortex (PLC) would induce LTD in an age-dependent manner and if dopamine receptors are involved in the expression of this LTD. We found four trains of stimulation at $50 \mathrm{~Hz}$ induced an LTD in the PFC of adult, but not peri-adolescent, rats. This $\mathrm{LTD}$ required intact $\mathrm{GABA}_{\mathrm{A}}$ receptor functioning and could also be blocked by dopamine $\mathrm{D}_{1}$ or $\mathrm{D}_{2}$ receptor antagonists. Bath application of selective $\mathrm{D}_{1}$ or $\mathrm{D}_{2}$ receptor agonists produced a significant facilitation or suppression in the field potential, respectively, and these effects were only observed in the adult PLC. Furthermore, neither $\mathrm{D}_{1}$ nor $\mathrm{D}_{2}$ stimualtion prior to HFS was able to facilitate LTD in the peri-adolescent PLC. Together, these results suggest dopamine receptor functionality in the PLC increases during adolescent development and it plays an important role in this late-maturating form of plasticity.

Corresponding author: Joshua M. Gulley, Ph.D., Department of Psychology, University of Illinois at Urbana-Champaign, 731 Psychology Bldg MC-716, 603 E Daniel St, Champaign IL 61820 USA. Tel: 001 (217) 265-6413; Fax: 001 (217) 244-5876; jgulley@illinois.edu.

Present address: Charles L. Cox, Professor and Chair, Department of Physiology, Michigan State University, Biomedical Physical Sciences Building, 567 Wilson Rd Rm 2201E, East Lansing MI 48824 USA. Tel: 001 (517) 884-5059; Fax: 001 (517) 432-1967; coxclee@msu.edu

Publisher's Disclaimer: This is a PDF file of an unedited manuscript that has been accepted for publication. As a service to our customers we are providing this early version of the manuscript. The manuscript will undergo copyediting, typesetting, and review of the resulting proof before it is published in its final citable form. Please note that during the production process errors may be discovered which could affect the content, and all legal disclaimers that apply to the journal pertain. 


\section{Introduction}

A large body of evidence, mostly from rodent models, suggests that the GABAergic system in the medial prefrontal cortex (mPFC) undergoes significant functional remodeling as individuals mature through adolescence into young adulthood (Erickson et al., 2002; Hashimoto et al., 2009; Fung et al., 2010; Caballero et al., 2014 a,b; Gonzalez-Burgos et al., 2015; Miyamae et al., 2017). One notable developmental change in prefrontal GABAergic cells is an increase in glutamatergic drive onto fast-spiking interneurons (FSIs), which results in an increased frequency of spontaneous excitatory postsynaptic currents (sEPSCs) in the FSIs of adults compared to peri-adolescents (Caballero et al., 2014a). Accordingly, it was also demonstrated that the frequency of spontaneous inhibitory postsynaptic currents (sIPSCs) recorded in glutamatergic pyramidal cells in the adult mPFC was increased compared to those in adolescents (Caballero et al., 2014a). Meanwhile, the total number of GABAergic cells in the PFC does not change significantly from peri-adolescence to adulthood (Caballero et al., 2014a; Willing and Juraska, 2015), suggesting that prefrontal GABAergic interneurons may increase their synaptic influence on pyramidal cells and thereby become integrated into the $\mathrm{mPFC}$ neural network where they provide critically important inhibitory regulation (Caballero et al, 2016). Consistent with this hypothesis, a series of in vivo studies demonstrated some aspects of GABAergic modulation of mPFC neuronal activity emerge only after mid- to late-adolescence. Specifically, male rats that were $\geq 45$ days old exhibited a long-term depression (LTD)-like change in the evoked field potential in the deep layer of the mPFC following high frequency stimulation (HFS; four trains at $50 \mathrm{~Hz}$ ) delivered in the ventral hippocampus (Cass et al., 2013; Caballero et al. 2014b; Thomases et al., 2014). In contrast, identical HFS delivered in the basolateral amygdala induced long-term potentiation (LTP) in the deep layer of mPFC that was independent of the age of the rat (Caballero et al., 2014b; Thomases et al., 2014). This ability of HFS in the ventral hippocampus to induce LTD in the $\mathrm{mPFC}$ may reflect a unique characteristic of the hippocampus-mPFC pathway, but it also may indicate that this lateemerging GABAergic modulation is an intrinsic property of the local network within the mPFC. A primary goal of the current study was to investigate the latter possibility by determining if a GABA-sensitive LTD could be induced in vitro by HFS within the MPFC of rats sacrified at pre- and post-adolescent stages of development.

The second aim of the current study was to investigate the role of dopamine receptors in the expression of HFS-induced LTD in the mPFC. Early studies using juvenile rats showed that dopamine plays a prominent role in regulating inhibitory tone in the mPFC (Seamans et al., 2001, 2004), partially through altering the excitability of interneurons (Gorelova et al., 2002; Trantham-Davidson et al., 2004). Later, it was found that there are significant changes in the expression of PFC dopamine receptors throughout adolescent development (Andersen et al., 2000; Brenhouse et al., 2008; Naneix et al., 2012) and accordingly, the dopaminergic regulation of inhibition has been shown to be influenced by age (Paul and Cox, 2013). The delayed maturation of dopamine's function in the $\mathrm{mPFC}$ is also consistent with the finding that prefrontal GABAergic cells increase their responsiveness to dopamine receptor stimulation during adolescent development. For example, after rats are 50 days old, nonFSIs become responsive to dopamine $\mathrm{D}_{1}$ receptor stimulation, whereas FSIs become 
responsive to $\mathrm{D}_{2}$ receptor-mediated increases in excitability (Tseng and O'Donnell, 2007a). Notably, the timing of these functional changes in dopamine's effects on interneurons is similar to when HFS-induced LTD emerges in the mPFC (Caballero et al. 2014b). Thus, we hypothesized that the ontogeny of HFS-induced LTD involves functional changes in both $\mathrm{D}_{1}$ and $\mathrm{D}_{2}$ receptors from peri-adolescence to adulthood such that the absence of LTD in the peri-adolescent $\mathrm{mPFC}$ is associated with a relatively reduced function of dopamine receptors.

\section{Materials and Methods}

\subsection{Subjects}

A total of 48 male Sprague-Dawley rats, which were offspring of breeders maintained in our facility, were used in these experiments. Rats from individual litters were weaned on postnatal day (P) 22. They were housed with same-sex littermates in groups of 2-3 per cage. Approximately half of the subjects were housed individually for about 24 hours before being sacrificed for recordings because their cagemates had been removed for recordings on the previous day. These cases were equally distributed across all experimental conditions. All rats were kept on a 12-h light/dark cycle (lights on at $0800 \mathrm{~h}$ ) in a temperature-controlled room with food and water available ad libitum. All procedures were performed during the light period of the cycle, were consistent with the 'Principals of Laboratory Animal Care' (NIH Publication no. 8523) and were approved by the IACUC at the University of Illinois, Urbana-Champaign, USA.

\subsection{Brain slices preparation}

Rats were assigned to be sacrificed for collection of brain slices when they were within the age ranges targeted for this study: P35-P45, P45-P55, P55-P65, P65-80, and P95-135. The mean (+ SEM) age at sacrifice for each of these groups, which were chosen based on previous studies of functional developmental of plasticity in the mPFC (Caballero et al., $2014 b$ ), was $37.4 \pm 1.09,49.0 \pm 0.91,59.5 \pm 1.76,71.7 \pm 1.2$, and $117 \pm 6.92$ days, respectively. On the day they were sacrificed, rats were deeply anesthetized with $55 \mathrm{mg} / \mathrm{kg}$ of sodium pentobarbital and decapitated. The brain was removed quickly and chilled in icecold, oxygenated slicing medium containing (in $\mathrm{mM}$ ): $2.50 \mathrm{KCl}, 1.25 \mathrm{NaH}_{2} \mathrm{PO}_{4}, 10.0$ $\mathrm{MgCl}_{2}, 0.50 \mathrm{CaCl}_{2}, 26.0 \mathrm{NaHCO}_{3}, 11.0$ glucose, and 234 sucrose. Tissue slices $(450 \mu \mathrm{m}$ thickness) containing the prelimbic cortex (PLC) were then cut with a vibrating tissue slicer (Pelco EasiSlicer, Ted Pella INC.) in the coronal orientation and transferred to a holding chamber in artificial cerebrospinal fluid (aCSF) containing (in $\mathrm{mM}$ ): $126 \mathrm{NaCl}, 2.50 \mathrm{KCl}$, $26.0 \mathrm{NaHCO}_{3}, 2.00 \mathrm{CaCl}_{2}, 1.25 \mathrm{MgCl}_{2}, 1.25 \mathrm{NaH}_{2} \mathrm{PO}_{4}$, and 10.0 glucose). Slices were kept in the aCSF gassed with $95 \% \mathrm{O}_{2} / 5 \% \mathrm{CO}_{2}$ first at $32^{\circ} \mathrm{C}$ for $20 \mathrm{~min}$ and then room temperature for $1 \mathrm{~h}$ before recordings.

\subsection{Field potential recording}

Brain slices were transferred to a recording chamber (Harvard apparatus, Holliston, MA) and submerged under a thin film of aCSF $\left(30-31^{\circ} \mathrm{C}\right)$ gassed with $95 \% \mathrm{O}_{2} / 5 \% \mathrm{CO}_{2}$. A dissecting stereoscope was used to identify specific regions of the slice and to aid in the placement of electrodes. Extracellular signals were obtained by using low resistance (300- 
$600 \mathrm{k} \Omega$ insulated tungsten electrodes (FHC, Inc., Bowdoinham, ME) placed in the deep layer of PLC.

Extracellular stimuli were delivered through a concentric bipolar tungsten electrode (FHC, Inc., Bowdoinham, ME) placed in either layer II/III or the deep layer of the PLC in line with the recording electrode as shown in the schematics (Fig. 1 and Fig. 2). Stimuli consisted of either single testing pulses ( $100 \mu$ s duration, $50-350 \mathrm{pA}$ at $0.067 \mathrm{~Hz}$ ) or 4 trains of HFS (100 pulses at $50 \mathrm{~Hz}$ per train, inter-train inverval $=10 \mathrm{~s}$ ). The intensity of the test pulse was adjusted to $50 \%$ of the intensity required to produce the maximum synaptic response. HFS trains or ligands were applied after a stable baseline response was obtained for at least 10 min. Ligands, which included bicuculline methiodide (BMI), SCH23390, sulpiride, DNQX, SKF38393, quinpirole or tetrodotoxin (TTX; all obtained from Tocris, Minneapolis, MN), were diluted in dimethyl sulfoxide (DMSO) or deionized water as stock solutions (10-40 $\mathrm{mM}$ ) and kept at $-20{ }^{\circ} \mathrm{C}$ before use. For all the drug applications, 5-20 $\mu$ stock solution or vehicle (DMSO or deionized water) was diluted in $200 \mathrm{ml}$ aCSF gassed with $95 \% \mathrm{O}_{2} / 5 \%$ $\mathrm{CO}_{2}\left(30-31^{\circ} \mathrm{C}\right)$ to the desired concentration (indicated in the figures or legends) and bath applied to the slice throughout the recording or for $10 \mathrm{~min}$ (indicated in the figures or legends). Recorded signals were amplified $(1,000 \mathrm{X}$ ), filtered (low pass $=10 \mathrm{kHz}$ ), sampled at $20 \mathrm{kHz}$ and digitally stored.

\subsection{Data analysis}

The slope of the first 1-2 ms of the field excitatory postsynaptic potential (fEPSP) was averaged in 1-min bins. For each slice, the averaged slope was then normalized to the mean slope of its 10-min baseline. All data are presented as mean \pm SEM. Statistical tests consisted of one- and two-way ANOVA (drug $\times$ age) with Tukey post hoc tests performed where appropriate.

\section{Results}

Field potential recordings were obtained in a total of 125 slices obtained from 48 male rats. A schematic diagram showing the approximate location of stimulating and recording electrodes is shown in Fig. 1. Single stimuli delivered in the superficial layer of the PLC typically produced one defletion in cells recorded from the deep layer of the PLC (Fig. 1A). Bath application of the AMPA receptor antagonist DNQX completely blocked this response, suggesting that this component is primarily mediated by an AMPA receptor-dependent postsynaptic response. Occasionally, we observed an additional deflection following single stimuli (Fig. 1B), which was resistant to DNQX. Further application of $1 \mu \mathrm{M}$ TTX completely blocked this early component, suggesting that the DNQX-insensitive deflection is a presynaptic fiber volley (Wilson and Cox, 2007). The fiber volley was not included in the analysis because it did not appear in all the recordings and only the slope of the DNQXsensitive component was used for analyses.

\subsection{Developmental changes in HFS-induced, GABA-sensitive LTD in the PLC}

As shown in Fig. 2, the effect of HFS on the fEPSP slope in the deep layer of the PLC was age-dependent. Following four trains of HFS delivered in the superficial layer, we found a 
sustained decrease of fEPSP slope in rats from groups older than P55 (Fig 1D-F). This was confirmed by significant one-way ANOVAs for the P65-80 and P95-135 groups $\left(\mathrm{F}_{49,235}=\right.$ $10.8, p<0.001$ and $\mathrm{F}_{49,261}=3.19, p<0.001$, respectively). In contrast, this same stimulation in younger rats failed to significantly change the fEPSP slope compared to baseline (Fig 1A-C). These effects were compared between groups by obtaining the mean fEPSP slope from the 30 to 40 min period following HFS (Fig. 1G). One-way ANOVA revealed a significant main effect of group $\left(\mathrm{F}_{4,22}=6.81, p=0.001\right)$. Post-hoc analysis suggested that the mean fEPSP slope in young adult rats $(\geq P 65)$ was significantly lower than that in peri-adolescent rats $(\leq \mathrm{P} 55)$. Slices obtained from rats between P55 and P65 also exhibited a mean reduction in fEPSP slope to about $\sim 80 \%$ of baseline, but this was not statistically significant.

To test whether the LTD we observed in the deep layer PLC of rats $\geq$ P55 was the result of specifically stimulating deep layer afferents originating from the superficial layers of the PLC, we investigated the effects of applying HFS within the deep layer in slices from young adult rats ( $\geq$ P65). With electrodes positioned as schematically depicted in Fig. 3, we found that HFS failed to induce LTD and instead produced a transient increase in the fEPSP slope (Fig. 3B). However, one-way ANOVA of the time course data suggested no significant differences in the fEPSP slope across all time points $\left(\mathrm{F}_{49,236}=1.01, p>0.05\right)$. The mean fEPSP slope from 16-20 min and 46-50 min, along with baseline, is shown in Fig. 3C. Oneway-ANOVA with repeated measures suggested no significant group difference $\left(\mathrm{F}_{2,10}=2.44\right.$, $p>0.05)$.

To test if delayed development of GABAergic signaling was involved in age-dependent differences in HFS-induced plasticity in the PLC, we studied the effects of inhibiting GABA signaling during recordings. Following applications of vehicle, we observed similar agedependent differences in HFS-induced plasticity as we had seen previously (Fig. 4). Specifically, there was a significant decrease in fEPSP slope in slices from young adults (P65-P80; Fig. 4C), but no significant change in those from peri-adolescent rats (P35-P45; Fig. 4B). However, HFS delivered in the presence of the $\mathrm{GABA}_{\mathrm{A}}$ receptor antagonist BMI $(1 \mu \mathrm{M})$ not only eliminated the LTD of the fEPSP, but led to a significant increase in the fEPSP slope in rats that were $\geq P 65$. There continued to be no significant effect of HFS in slices from peri-adolescent rats. Analysis of the mean slope of the fEPSP from 30-40 min post-HFS (Fig. 4D) revealed a significant main effect of drug $\left(\mathrm{F}_{1,20}=20.4, p<0.001\right)$ and a drug by age interaction $\left(\mathrm{F}_{1,20}=8.60, p=0.008\right)$. Post-hoc analysis suggested a significant effect of BMI only in the young adult group.

\subsection{Potenital role of dopamine in HFS-induced LTD}

To determine if dopamine receptor activation was required for the HFS-induced LTD observed in young adult rats, we applied dopamine receptor antagonists to slices for the duration of recordings (Fig. 5). As shown in Fig. 5B, we found that HFS failed to produce a lasting decrease in the fEPSP slope with the presence of either the $\mathrm{D}_{1}(\mathrm{SCH} 23390 ; 10 \mu \mathrm{M})$ or the $\mathrm{D}_{2}$ receptor antagonist (sulpiride; $10 \mu \mathrm{M}$ ). Analysis of the mean slope of the fEPSP from 30-40 min post-HFS with one-way ANOVA revealed a significant effect of group 
$\left(\mathrm{F}_{2,13}=18.61, \mathrm{p}<0.001\right)$. Post-hoc comparisons suggested that both drug groups were significantly different from control (Fig. 5C).

We next determined if application of dopamine receptor agonists alone was sufficient to produce long-term changes in the fEPSP and if agonist-induced changes were age-dependent (Fig. 6). As shown in Fig. 6B, fEPSP recordings from both peri-adolescent and young adult brain slices remained stable and relatively unchanged following vehicle exposure. Following application of a $\mathrm{D}_{1}$ agonist (SKF38393; $10 \mu \mathrm{M}$ ), the fEPSP increased significantly in slices from young adult rats. There was also a small increase in the fEPSP from peri-adolescent rats, but this change was not significantly different from baseline (Fig. 6C). The $\mathrm{D}_{2}$-like receptor agonist quinpirole $(1 \mu \mathrm{M})$ also had a small, but non-significant effect on the fEPSP in peri-adolescent rats. In slices from young adult rats, quinpirole $(1 \mu \mathrm{M})$ led to a significant decrease in the fEPSP (Fig. 6D) that was similar to the decrease observed in this age group following HFS. Analysis of the mean slope of the fEPSP from 30-40 min post-HFS (Fig. $6 \mathrm{E})$ revealed a significant main effect of drug $\left(\mathrm{F}_{2,23}=50.1, p<0.001\right)$ and a drug by age interaction $\left(F_{2,23}=13.7, p<0.001\right)$. Post-hoc tests suggested that within the young adult group, both the $\mathrm{D}_{1}$ and $\mathrm{D}_{2}$-like receptor agonist conditions were significantly different from vehicle. Within each drug condition, there was also a significant difference between the young adult and peri-adolescent groups.

To further elucidate the role of dopamine receptors in HFS-induced LTD, we next determined if their activation prior to delivery of the stimulating pulse would impact HFSinduced LTD. Vehicle exposure just prior to HFS delivery had no impact on the plasticity induced in slices from young adult rats (Fig. 7A). Stimulation of $\mathrm{D}_{1}$ receptors increased the fEPSP in slices from young adult, but not peri-adolescent rats as we observed in our prior experiment (cf. Fig. 6B), but subsequent application of HFS reversed this effect and returned the fEPSP to just below $100 \%$ of its baseline prior to drug application (Fig. 7B). Stimulation of $\mathrm{D}_{2}$ - like receptors (Fig. 7C) decreased the fEPSP in slices from both peri-adolescent and young adult rats to a similar extent that we had seen in our prior experiment (cf. Fig. 6C). Following HFS, the fEPSP recorded from young adult rats decreased further below baseline while the fEPSP recorded from peri-adolescents was relatively stable. Two-way ANOVA of the mean slope of the fEPSP 30-40 min post-HFS (Fig. 7D) revealed a significant main effect of drug $\left(\mathrm{F}_{2,25}=13.6, p<0.001\right)$ and age $\left(\mathrm{F}_{1,25}=\right.$ 25.0, $p<0.001$ ). Post-hoc tests showed that only the $\mathrm{D}_{1}$ agonist significantly altered HFSinduced changes in the fEPSP and this was the case only in slices from young adult rats.

\section{Discussion}

Using in vitro extracellular recordings, the current study revealed that GABA-sensitive plasticity in the mPFC emerged in the late peri-adolescent period in male rats. Specifically, HFS delivered in the superficial layer of the PLC produced a persistent decrease in evoked field potential in the deep layer PLC in rats > P55 and this decrease was blocked by a $\mathrm{GABA}_{\mathrm{A}}$ receptor antagonist. We further demonstrated that dopamine signaling was involved in the expression and, potentially, in the ontogeny of HFS-induced LTD in the PLC. This is evidenced by the findings that antagonism of either $D_{1}$ or $D_{2}$ receptors prevented the expression of HFS-induced LTD in the adult PLC and that both $\mathrm{D}_{1}$ and $\mathrm{D}_{2}$-like receptors in 
the peri-adolescent PLC were less responsive to their respective agonists when compared to the adult group. Together, these results indicate that a functional up-regulation in prefrontal dopamine receptors may be an important factor enabling a late-maturing GABA system to regulate the $\mathrm{mPFC}$ neural network.

As mentioned above, findings by Caballero and colleagues suggest a GABA-related developmental alteration in the deep layer cells that respond to hippocampal input (Caballero et al., 2014b). Besides afferent innervation from subcortical regions, deep layer cells in the mPFC also receive projections from the superficial layers (Yang et al., 1996). Several early investigations have demonstrated that under certain conditions, such as when $\mathrm{GABA}_{\mathrm{A}}$ receptor are blocked and $3 \mu \mathrm{M}$ dopamine is bath-applied for $40 \mathrm{~min}$ prior to stimulation, HFS will induce long-term plastic change in glutamtergic transmission between the superficial and the deep layer in the juvenile or adult mPFC (Otani et al., 2003; Huang et al., 2004; Kolomiets et al., 2009; Sheynikhovich et al., 2013). However, GABA may play a prominent role in modulating HFSrelated activity in the mPFC and significant developmental changes are likely to occur to this modulation during adolescence ( Caballero et al., 2014b; Caballero et al., 2016; Caballero and Tseng, 2016). To test this hypothesis, we kept endogenous GABA transmission intact and compared the effect of HFS on the field potential across age. We found that HFS delivered within the PLC indeed produced an LTD and this effect was apparent only in rats > P55. We further comfirmed that the expression of LTD was sensitive to the antagonism of $\mathrm{GABA}_{\mathrm{A}}$ receptors, just as was demonstrated for the LTD observed in the hippocampus-mPFC circuit (Caballero et al., 2014b). In fact, with $\mathrm{GABA}_{\mathrm{A}}$ receptors blocked, HFS from the hippocampus (Caballero et al., 2014b) or delivered in the superficial layer produces an LTP in the deep layer cells in the adult mPFC. Collectively, these data suggest that as the mPFC matures, cells in the deep layer become more responsive to HFS-induced plasticity and the net result of LTD may be due to a greater increase in inhibition relative to excitation. Such a significant shift in the excitationinhibition balance may alter how information is processed in the mPFC network and since it emerges when animals are approaching adulthood, this GABA-related function may be one of the limiting factors for the mPFC to fully mature (Caballero and Tseng., 2016).

The up-regualtion in the GABA tone that may underly the ontogeny of HFS-induced LTD could be explained by a series of changes in interneurons and pyramidal cells during lateadolescence. GABAergic cells in the mPFC are generally categorized as FSIs and nonFSIs based on their electrophysiological properties. According to several studies, functional upregulation after $\mathrm{P} 45$ in male rats seems to occur preferentially in FSIs that express parvalbumin (PV) protein (Caballero et al., 2013; Caballero et al., 2014a; Tseng and O'Donnell, 2007a). The FSIs increase in number and upregulate their level of PV protein expression, as well as become more responsive to glutamate (Caballero et al., 2013). Since FSIs are believed to provide a significant GABA influence in the $\mathrm{mPFC}$, especially in layer V (Naka and Adesnik, 2016), these changes likely result in a gain in inhibitory tone in the mPFC during late peri-adolescence (Caballero et al., 2016). At the same time, pyramidal cells become more sensitive to GABA input during periadolesent development (Datta et al., 2015). Specifically, there is an increase in the mRNA of the $a_{1}$ subunit-containing $G_{A B A_{A}}$ receptor in pyramidal cells and these receptors selectively respond to synaptic input from PV-containing cells (Klausberger et al., 2002). Meanwhile, the expression of $a_{5}$-containing 
$\mathrm{GABA}_{\mathrm{A}}$ receptors in pyramidal cells decreases progressively from adolescence to adulthood and these receptors are found in the apical dendrites responding to input from non-FSIs (Datta et al., 2015). These changes in $a_{1}$ - and $a_{5}$-containing $\mathrm{GABA}_{\mathrm{A}}$ receptors are suggested to shift the inhibitory tone in pyramidal cells from dendritic to a more robust perisomatic locus during periadolescent development (Datta et al., 2015). Accordingly, analysis of sIPSCs in pyramidal cells shows that these inhibitory currents tend to have a faster decay time in the adult compared to the peri-adolescent mPFC (Hashimoto et al., 2009). Thus, as the mPFC matures, there is a potential increase in the maximum number of inhibitory currents that could occur in pyramidal cells at a given time. In addition, the expression of extrasynaptic $\mathrm{GABA}_{\mathrm{A}}$ receptors that contain $\delta$ subunits increases significantly in layer $\mathrm{V}$ pyramidal cells from adolescence to adulthood and this may provide additional sensitivity to ambient GABA for tonic inhibition (Datta et al., 2015; Zheleznova et al., 2009). Together, these developmental changes in the interneuron-pyramidal cell interaction are predicted to lead to novel patterns of inhibitory modulation in the mPFC (Caballero and Tseng., 2016). Consistent with this notion, the current study and others (Caballero et al., 2014b) demonstrate that HFS triggers a prominent GABAergic modulation of population neural activity in the mPFC that only emerges in the relatively late stage of adolescent development. Future studies are required to reveal the potential functional impact of this LTD on the mPFC network.

In addition to development of GABA signaling, functional changes in dopamine receptors are also likely involved in the ontogeny of the HFS-induced LTD. As mentioned above, dopamine plays an important role in regulating inhibition in the mPFC (Seamans and Yang, 2004) and there are numerous developmental changes in dopamine receptors that may influence GABA functions (Paul and Cox, 2013; Tseng and O'Donnell, 2007a). Notably, periadolescent alterantions in dopamine signaling by cocaine exposure has been shown to abolish the HFS-induced LTD in the ventral hippocampus-mPFC circuit in adulthood (Cass et al., 2013). To investigate the relationship between dopamine signaling and the HFSinduced LTD we observed, we first demonstrated that either $\mathrm{D}_{1}$ or $\mathrm{D}_{2}$ receptor antagonist prevented the expression of LTD. Notably, the moderate concentrations of SCH23390 and sulpiride used in the current study have been commonly seen or comparable to what have been used in other in vitro electrophysiological investigations (Banks et al., 2015; Paul and Cox., 2013; Seamans and Yang 2004; Xu and Yao, 2010) and would be unlikely to compromise the selectivity of these antagonists. Thus, both $\mathrm{D}_{1^{-}}$and $\mathrm{D}_{2}$ dopamine receptors are necessary for HFS to induce LTD in the PLC.

Early investigations found that high concentration $(>50 \mu \mathrm{M})$ of dopamine or dopamine releaser applied to the mPFC slice suppresses fEPSP and produces an LTD-like response (LawTho et al., 1995; Mair and Kauer, 2007). In this regard, the HFS-induced LTD may be explained by dopamine's effect on the fEPSP and the absence of LTD in the adolescent $\mathrm{mPFC}$ may be due to a reduced dopamine receptor function. To test this hypothesis, we examined the effect of $D_{1}$ and $D_{2} / D_{4}$ agonists on the field potential in the adolescent and adult $\mathrm{mPFC}$. These receptors have been suggested to play an important role in modulating both interneuron and pyramidal cell activity (Onn et al., 2006; Zhong and Yan, 2016) and their affinity to respective agonist increases during adolescence (Tarazi and Baldessarini, 2000). Moreover, we chose quinpirole to stimulate $D_{2} / D_{4}$ receptors so our results could be 
compared directly to several early findings showing developmental changes in the effect of this drug on evoked EPSP (Tseng and O'Donnell, 2007b) and interneuron excitability (Tseng and O'Donnell, 2007a) in the mPFC. We found that quinpirole produced a persistent decrease in the field potential that seemed to mimic an LTD while SKF38393 led to an significant increase in the field potential. In contrast, neither of these drugs produced significant changes in brain slices from rats sacrificed between P35 and P45. These results support our hypothesis that there is a significant functional increase in dopamine receptors after P45, which may be a contrubting factor for the ontogeny of the HFS-induced LTD. However, the effects of $\mathrm{D}_{1}$ and $\mathrm{D}_{2} / \mathrm{D}_{4}$ stimulation that we observed in the adult mPFC appear contradictory to our finding that both $\mathrm{D}_{1}$ and $\mathrm{D}_{2}$ antagonist blocked the expression of LTD, especially because the $\mathrm{D}_{1}$ agonist led to an increase in the field potential that is opposite to an LTD.

It is notable that approximately $75-80 \%$ of $\mathrm{D}_{1}, \mathrm{D}_{2}$ and $\mathrm{D}_{4}$ receptors in the $\mathrm{mPFC}$ are located on pyramidal cells (Santana et al., 2009; Almeida and Mengod, 2010). Thus, it is likely that the effects we observed of the dopamine agonists were primarily driven by the actions of these drugs on pyramidal cells. In fact, the effects of these agonists on the field potential, as well as the age-related changes we observed, are consistent with previous studies showing dopamine's effect on excitatory currents or potentials in pyramidal cells. For example, in rats $\geq P 45$, selective activation of $\mathrm{D}_{1}$ receptors was found to increase NMDA receptormediated depolarization in the deep layer pyramidal cells in the mPFC (Tseng and O'Donnell, 2005; Flores-Barrera et al., 2014). Quinpirole was found to decrease the AMPA receptor-mediated EPSP in deep layer pyramidal cells and this effect was more pronounced in rats older than P50 (Tseng and O'Donnell, 2007b). In this regard, the expression of HFSinduced LTD may not mainly rely on dopamine's action on the pyramidal cells. This notion is supported by our receptor occlusion results. In the adult mPFC, HFS was able to substantially decrease the field potential after $10 \mathrm{~min}$ application of either SKF38393 or quinpirole. Together, our results indicate that the HFS-induced LTD is unlikely to be caused by global activation of dopamine receptors in the $\mathrm{mPFC}$, or more specifically in pyramidal cells, but may be relying more on dopamine-mediated changes in interneurons. This hypothesis is consistent with developmental changes in the dopamine release pools in the mPFC. It is known that dopamine cells in the ventral tegmental area project directly onto superficial and deep layers in the MPFC and contact both pyramidal cells and interneurons (Benes et al., 1993; Sesack et al., 1995). During periadolescent development, there is a significant increase in the percentage of GABA cells that have dopamine varicosities nearby as well as the number of dopamine varicosity near a single GABA cell (Benes at al., 1996). Therefore, it is possible that dopamine release following HFS may have an increased impact on interneurons in adulthood comparing to peri-adolescence, resulting in an overall suppression in synaptic transmission.

Based on the available evidence from the literature, we speculate that the HFS-induced LTD is an augmented inhibition that masks potential changes in excitation rather than a mere reduction in excitation. The putative enhanced inhibition is due to, at least partially, $\mathrm{D}_{1}$ - and $\mathrm{D}_{2}$ like receptor mediated facilitation in the GABAergic output (Tseng and O'Donnell, 2007a). This hypothesized mechanism is based on the following. First, it is well established that dopamine elevates inhibitory tone in adult $\mathrm{mPFC}$ and the increase in inhibitory function 
could last over 3040 min (Seamans et al., 2001; Kroner and Lavin, 2012; Paul et al., 2013; Kang et al, 2016). This prolonged action of dopamine on inhibition seems consistent with the post-HFS changes found in the current study. Second, non-FSIs and and FSIs start to respond to the excitatory effect of $\mathrm{D}_{1}$ and $\mathrm{D}_{2} / \mathrm{D}_{4}$ agonists, respectively, after P50 (Tseng and O'Donnell, 2007a). The timing when these additional dopamine-mediated inhibitory influences start to appear in the MPFC is close to when HFS-induced LTD is possible. Lastly, the enhanced inhibition following HFS is not inconsistent with the potential increase in excitation that may likely co-exist at a limited set of synapses and can not be detected in the populational responses in the current study (Laroche et al., 2000). The potentially increased glutamate transmission may provide further drive on nearby interneurons and the net effect is a reduction in the populational activity. An alternative explanation is that the adult-level GABA inhibition limits the post-synaptic depolarization following HFS, resulting in a low $\mathrm{Ca}^{2+}$ rise that is known to lead to LTD (Hirsch and Crepel, 1992; Collingridge et al., 2010). The absence of LTD in peri-adolescent PLC could be due to a relatively weak and inmature GABA tone that is unable to attenuate the HFS-induced depolarization. Future studies are required to directly test these hypotheses.

Another noteworthy finding in the current study is that the HFS delivered in the deep layer did not produce significant changes in the cells that are also in the the deep layer. Because the deep-layer pyramidal cells in the mPFC also receive intra-layer glutamate influence, we sought to determine if there is also a GABA-sensitive LTD regulates intra-layer high frequency transmission. However, it seems that the GABA-sensitive LTD in the deep layer is elicited specifically by high frequency superficial layer input. In contrast to our results, a recent in vitro study showed that the HFS delivered in the superficial layer in the mPFC produced an LTP in the same layer (Konstantoudaki et al., 2018) and such LTP was insensitive to $\mathrm{GABA}_{\mathrm{A}}$ receptor antagonist. These differential expressions of synaptic plasticity could be explained by the cellular arrangment in the mPFC. For example, the intrasuperficial layer LTP could be mediated by the horizontal "long range" glutamate projections between pyramidal cells specifically found in layer 2/3 (Kritzer and GoldmanRakic, 1995). In contrast, layer V pyramidal cells and surrounding interneurons are hypothesized to be organized in aggregates that resemble the structure of columns (as in non-humam primates) or barrels (as in rodents) in other neocorteces (Naka and Adesnik, 2016). Activity in layer V pyramidal cells readily recruits surrounding interneurons, which in turn elicits inhibition on nearby excitatory and inhibitory cells (Naka and Adesnik, 2016). This arrangement may be important for confining activity in a given neural aggregate or column to prevent unnecessary influences on neighboring columns. In this regard, the lack of significant changes following HFS delivered in the deep layer could be due to the intercolumn inhibition that did not allow signal propagation between columns. However, it is not clear if we would have seen any significant changes in the field potential when the electrode placement had been further manipulated. Future investigations are required to determine the cellular and molecular mechanisms underlying this LTD.

In conclusion, our results reveal a GABA-sensitive regulation in the deep layer mPFC that emerges during late-adolescence and is activated by HFS, which is in keeping with several in vivo findings (Caballero et al., 2014b; Cass et al., 2013). While the functional significance of this GABA-regulation requires further investigation, our results suggest that it is 
expressed when the HFS also becomes able to produce LTP in the mPFC. Perhaps as suggested earlier, this inhibitory function may serve as an "anti-LTP" or a threshold control mechanism to prevent too much LTP saturating in the mPFC network (Laroche et al., 2000). With a focus on the developmental changes in $\mathrm{MPFC}$, the current study further demonstrates an increase in the dopamine receptors that may play an important role in the maturation of the HFS-induced LTD. Given the well-studied dopamine-GABA interplay, this HFS-induced LTD may also serve to regulate the signal-to-noise level in the deep layer output cells (Seamans et al., 2001; 2004; Caballero and Tseng, 2016). Furthermore, the much delayed maturation of dopamine and GABA system revealed in the current study indicates a potential window of vulnerability (Cass et al., 2013; Thomases et al., 2014) in the lateadolescence when humans start to experiment with drugs that have high potential in disrupting the normal development of these neurotransmitter systerms (Gulley and Juraska, 2013).

\section{Acknowledgements}

The authors thank Dr. Kush Paul, Dr. Joseph Beatty, Jacqueline Fenn and Kathleen Louis for technical assistance. This work was supported by NIH grant DA029815.

\section{References}

Almeida J de, Mengod G (2010) D2 and D4 dopamine receptor mRNA distribution in pyramidal neurons and GABAergic subpopulations in monkey prefrontal cortex: implications for schizophrenia treatment. Neurosci. 170:1133-9.

Andersen SL, Thompson AC, Rutstein M, Hosterer JC, Teicher MH (2000) Dopamine Receptor Pruning in Prefrontal Cortex During the Periadolescent Period in Rats. Synapse 37:167-169. [PubMed: 10881038]

Banks PJ, Burroughs AC, Barker GR, Brown JT, Warburton EC, Bashir ZI (2015) Disruption of hippocampal-prefrontal cortex activity by dopamine D2R-dependent LTD of NMDAR transmission. Proc Natl Acad Sci U S A. 112:11096-101. [PubMed: 26286993]

Benes FM, Vincent SL, Molloy R (1993) Dopamine-immunoreactive axon varicosities form nonrandom contacts with GABA-immunoreactive neurons of rat medial prefrontal cortex. Synapse. 15:285-95. [PubMed: 8153876]

Benes FM, Vincent SL, Molloy R, Khan Y (1996) Increased interaction of dopamineimmunoreactive varicosities with GABA neurons of rat medial prefrontal cortex occurs during the postweanling period. Synapse 23:237-45. [PubMed: 8855508]

Brenhouse HC, Sonntag KC, Andersen SL (2008) Transient D1 dopamine receptor expression on prefrontal cortex projection neurons: relationship to enhanced motivational salience of drug cues in adolescence. J Neurosci. 28:2375-82. [PubMed: 18322084]

Caballero A, Flores-Barrera E, Cass DK, Tseng KY (2014a) Differential regulation of parvalbumin and calretinin interneurons in the prefrontal cortex during adolescence. Brain Struct. Funct 219, 395-406. [PubMed: 23400698]

Caballero A, Granberg R, Tseng KY (2016) Mechanisms contributing to prefrontal cortex maturation during adolescence. Neurosci Biobehav Rev. 70:4-12. [PubMed: 27235076]

Caballero A, Thomases DR, Flores-Barrera E, Cass DK, Tseng KY (2014b) Emergence of GABAergic-dependent regulation of input-specific plasticity in the adult rat prefrontal cortex during adolescence. Psychopharmacol 231:1789-1796.

Caballero A, Tseng KY (2016) GABAergic Function as a Limiting Factor for Prefrontal Maturation during Adolescence. Trends Neurosci 39:441-8. [PubMed: 27233681] 
Cass DK, Thomases DR, Caballero A, Tseng KY (2013) Developmental disruption of gammaaminobutyric acid function in the medial prefrontal cortex by noncontingent cocaine exposure during early adolescence. Biol Psychiatry 74:490-501. [PubMed: 23558299]

Collingridge GL, Peineau S, Howland JG, Wang YT (2010) Long-term depression in the CNS. Nat Rev Neurosci 11:459-473. [PubMed: 20559335]

Datta D, Arion D, Lewis DA (2015) Developmental Expression Patterns of GABAA Receptor Subunits in Layer 3 and 5 Pyramidal Cells of Monkey Prefrontal Cortex. Cereb Cortex. 25:2295305. [PubMed: 24610118]

Erickson SL, Lewis DA (2002) Postnatal development of parvalbumin- and GABA transporterimmunoreactive axon terminals in monkey prefrontal cortex. J. Comp. Neurol. 448, 186-202. [PubMed: 12012429]

Flores-Barrera E, Thomases DR, Heng LJ, Cass DK, Caballero A, Tseng KY (2014) Late adolescent expression of GluN2B transmission in the prefrontal cortex is input-specific and requires postsynaptic protein kinase A and D1 dopamine receptor signaling. Biol Psychiatry. 75:508-16. [PubMed: 24041503]

Fung SJ, Webster MJ, Sivagnanasundaram S, Duncan C, Elashoff M, Weickert CS (2010) Expression of interneuron markers in the dorsolateral prefrontal cortex of the developing human and in schizophrenia. Am. J. Psychiatry 167, 1479-1488. [PubMed: 21041246]

Gonzalez-Burgos G, Miyamae T, Pafundo DE, Yoshino H, Rotaru DC, Hoftman G, Datta D, Zhang Y, Hammond M, Sampson AR, Fish KN, Ermentrout GB, Lewis DA (2015) Functional maturation of GABA synapses during postnatal development of the monkey dorsolateral prefrontal cortex. Cereb Cortex 25:4076-93. [PubMed: 24904071]

Gorelova N, Seamans JK, Yang CR (2002) Mechanisms of dopamine activation of fast-spiking interneurons that exert inhibition in rat prefrontal cortex. J Neurophysiol 88:3150-66. [PubMed: 12466437]

Gulley JM, Juraska JM (2013) The effects of abused drugs on adolescent development of corticolimbic circuitry and behavior. Neuroscience 249:3-20. [PubMed: 23711583]

Hashimoto T, Nguyen QL, Rotaru D, Keenan T, Arion D, Beneyto M, Gonzalez-Burgos G, Lewis DA (2009) Protracted developmental trajectories of GABAA receptor alpha1 and alpha2 subunit expression in primate prefrontal cortex. Biol Psychiatry. 65:1015-23. [PubMed: 19249749]

Hirsch JC, Crepel F (1992) Postsynaptic calcium is necessary for the induction of LTP and LTD of monosynaptic EPSPs in prefrontal neurons: An in vitro study in the rat. Synapse. 10:1735

Huang YY, Simpon E, Kellendonk C, Kandel ER (2004) Genetic evidence for the bidirectional modulation of synaptic plasticity in the prefrontal cortex by D1 receptors. Proc Natl Acad Sci 101: 3236-3241. [PubMed: 14981263]

Kang S, Paul K, Hankosky ER, Cox CL, Gulley JM (2016) D1 receptor-mediated inhibition of medial prefrontal cortex neurons is disrupted in adult rats exposed to amphetamine in adolescence. Neurosci. 324:40-49.

Klausberger T, Roberts JD, Somogyi P (2002) Cell Type- and Input-Specific Differences in the

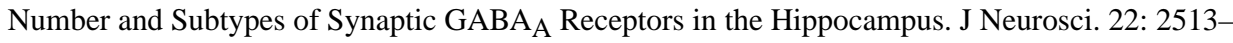
21. [PubMed: 11923416]

Kolomiets B, Marzo A, Caboche J, Vanhoutte P, Otani S (2009) Background dopamine concentration dependently facilitates long-term potentiation in rat prefrontal cortex through postsynaptic activation of extracellular signal-regulated kinases. Cereb Cortex 19:2708-18. [PubMed: 19282455]

Konstantoudaki X, Chalkiadaki K, Vasileiou E, Kalemaki K, Karagogeos D, Sidiropoulou K (2018) Prefrontal cortical-specific differences in behavior and synaptic plasticity between adolescent and adult mice. J Neurophysiol. 119:822-833. [PubMed: 29167323]

Kritzer MF, Goldman-Rakic PS (1995) Intrinsic circuit organization of the major layers and sublayers of the dorsolateral prefrontal cortex in the rhesus monkey. J Comp Neurol. 359:131-43. [PubMed: 8557842]

Kroener S, Lavin A (2010) Altered dopamine modulation of inhibition in the prefrontal cortex of cocaine-sensitized rats. Neuropsychopharmacology 35:2292-304. [PubMed: 20664581] 
Law-Tho D, Desce JM, Crepel F (1995) Dopamine favours the emergence of long-term depression versus long-term potentiation in slices of rat prefrontal cortex. Neurosci Lett. 188:125-8. [PubMed: 7792056]

Laroche S, Davis S, Jay TM (2000) Plasticity at hippocampal to prefrontal cortex synapses: dual roles in working memory and consolidation. Hippocampus 10:438-446. [PubMed: 10985283]

Mair RD, Kauer JA (2007) Amphetamine depresses excitatory synaptic transmission at prefrontal cortical layer V synapses. Neuropharmacology. 52:193-9. [PubMed: 16895728]

Matsuda Y, Marzo A, Otani S (2006) The Presence of Background Dopamine Signal Converts LongTerm Synaptic Depression to Potentiation in Rat Prefrontal Cortex. J Neurisci 26:4803-10.

Miyamae T, Chen K, Lewis DA, Gonzalez-Burgos G (2017) Distinct physiological maturation of parvalbumin-positive neuron subtypes in mouse prefrontal cortex. J Neurosci. 37: 4883-4902. [PubMed: 28408413]

Naka A, Adesnik H (2016) Inhibitory Circuits in Cortical Layer 5. Front Neural Circuits 10:35. [PubMed: 27199675]

Naneix F, Marchand AR, Di Scala G, Pape JR, Coutureau E (2012) Parallel maturation of goaldirected behavior and dopaminergic systems during adolescence. J Neurosci. 32:16223-32. [PubMed: 23152606]

Onn SP, Wang XB, Lin M Grace AA (2006) Dopamine D1 and D4 Receptor Subtypes Differentially Modulate Recurrent Excitatory Synapses in Prefrontal Cortical Pyramidal Neurons. Neuropsychopharmacology 31:318-338. [PubMed: 16052247]

Otani S, Daniel H, Roisin M, Adaptatifs P, Vi UP (2003) Dopaminergic Modulation of Longterm Synaptic Plasticity in Rat Prefrontal Neurons. Cereb Cortex 13:1251-6. [PubMed: 14576216]

Paul K, Cox CL (2013) Age-dependent actions of dopamine on inhibitory synaptic transmission in superficial layers of mouse prefrontal cortex. J Neurophysiol. 109:1323-32.. [PubMed: 23221420]

Santana N, Mengod G, Artigas F (2009) Quantitative analysis of the expression of dopamine D1 and D2 receptors in pyramidal and GABAergic neurons of the rat prefrontal cortex. Cereb Cortex 19:849-860. [PubMed: 18689859]

Seamans JK, Gorelova N, Durstewitz D, Yang CR (2001) Bidirectional Dopamine Modulation of GABAergic Inhibition in Prefrontal Cortical Pyramidal Neurons. J Neurosci. 21:3628-38. [PubMed: 11331392]

Seamans JK, Yang CR (2004) The principal features and mechanisms of dopamine modulation in the prefrontal cortex. Prog Neurobiol 74:1-57. [PubMed: 15381316]

Sesack SR, Snyder CL, Lewis DA (1995) Axon terminals immunolabeled for dopamine or tyrosine hydroxylase synapse on GABA-immunoreactive dendrites in rat and monkey cortex. J Comp Neurol. 363:264-80. [PubMed: 8642074]

Sheynikhovich D, Otani S, Arleo A (2013) Dopaminergic control of long-term depression/longterm potentiation threshold in prefrontal cortex. J Neurosci 33:13914-13926. [PubMed: 23966711]

Tarazi FI, Baldessarini RJ (2000) Comparative postnatal development of dopamine D1, D2 and D4 receptors in rat forebrain. Int. J. Devl. Neurosci 18:29-37.

Thomases DR, Cass DK, Meyer JD, Caballero A, Tseng KY (2014) Early Adolescent MK-801 Exposure Impairs the Maturation of Ventral Hippocampal Control of Basolateral Amygdala Drive in the Adult Prefrontal Cortex. J Neurosci 34:9059-9066. [PubMed: 24990926]

Trantham-Davidson H, Neely LC, Lavin A, Seamans JK (2004) Mechanisms underlying differential D1 versus D2 dopamine receptor regulation of inhibition in prefrontal cortex. J Neurosci 24:10652-9. [PubMed: 15564581]

Tseng KY, O'Donnell P (2005) Post-pubertal emergence of prefrontal cortical up states induced by D1-NMDA co-activation. Cereb Cortex. 15:49-57. [PubMed: 15217899]

Tseng KY, O’Donnell P (2007a) Dopamine modulation of prefrontal cortical interneurons changes during adolescence. Cereb Cortex 17:1235-1240. [PubMed: 16818475]

Tseng KY, O’Donnell P (2007b) D2 Dopamine Receptors Recruit a GABA Component for Their Attenuation of Excitatory Synaptic Transmission in the Adult Rat Prefrontal Cortex. Synapse 61:843-50. [PubMed: 17603809]

Willing J, Juraska JM (2015) The timing of neuronal loss across adolescence in the medial prefrontal cortex of male and female rats. Neurosci. 301:268-75. 
Wilson BM, Cox CL (2007) Absence of metabotropic glutamate receptor-mediated plasticity in the neocortex of fragile X mice. Proc Natl Acad Sci 104:2454-9. [PubMed: 17287348]

Xu TX, Yao WD (2010) D1 and D2 dopamine receptors in separate circuits cooperate to drive associative long-term potentiation in the prefrontal cortex. Proc Natl Acad Sci U S A 107:1636616371. [PubMed: 20805489]

Yang CR, Seamans JK, Gorelova N (1996) Electrophysiological and morphological properties of layers V-VI principal pyramidal cells in rat prefrontal cortex in vitro. J Neurosci 1619041921.

Zheleznova NN, Sedelnikova A, Weiss DS (2009) Function and modulation of $\delta$-containing GABAA receptors. Psychoneuroendocrinology 34S1:S67-S73.

Zhong P, Yan Z (2016) Distinct Physiological Effects of Dopamine D4 Receptors on Prefrontal Cortical Pyramidal Neurons and Fast-Spiking Interneurons. Cereb Cortex. 26: 180-191. [PubMed: 25146372] 
- $\quad$ HFS induces plasticity in the prelimbic cortex of adult but not adolescent rats

- This plasticity in adults is sensitive to $\mathrm{GABA}_{\mathrm{A}}$ and dopamine receptor antagonism

- Its absence in adolescents may be due partly to immature dopamine receptor function 


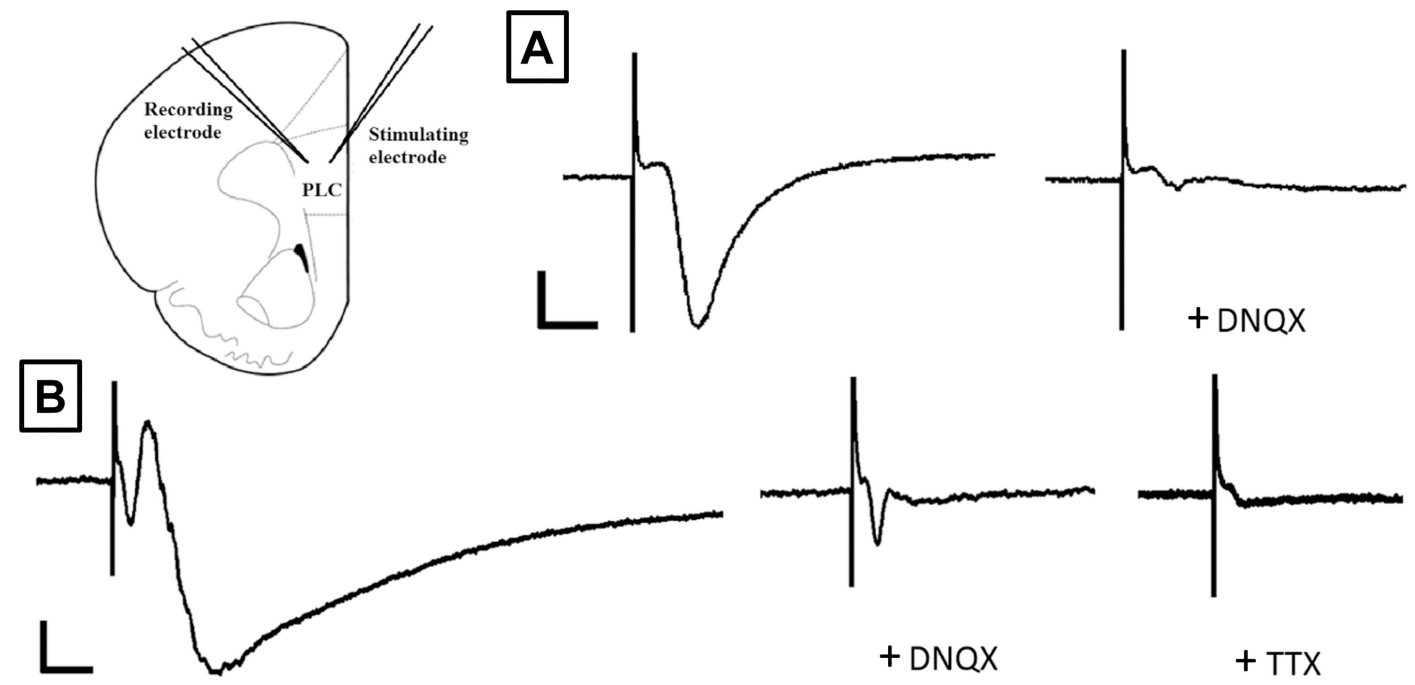

Figure 1.

Schematic diagram of stimulating and recording electrode placements in the prelimbic cortex (PLC) and sample traces showing the components of the fEPSP that were analyzed. Single testing pulses $(100 \mu$ s duration; $50-350 \mathrm{pA}$ at $0.067 \mathrm{~Hz})$ produced either single $(\mathbf{A})$ or double (B) deflections that could be blocked by DNQX $(10 \mu \mathrm{M})$ or DNQX $(10 \mu \mathrm{M})+$ TTX $(1 \mu \mathrm{M})$. Calibrattion axes: $50 \mu \mathrm{V}$ for the ordinate; $50 \mathrm{~ms}$ for the abscissa in $\mathrm{A}, 20 \mathrm{~ms}$ for the abscissa in B. 

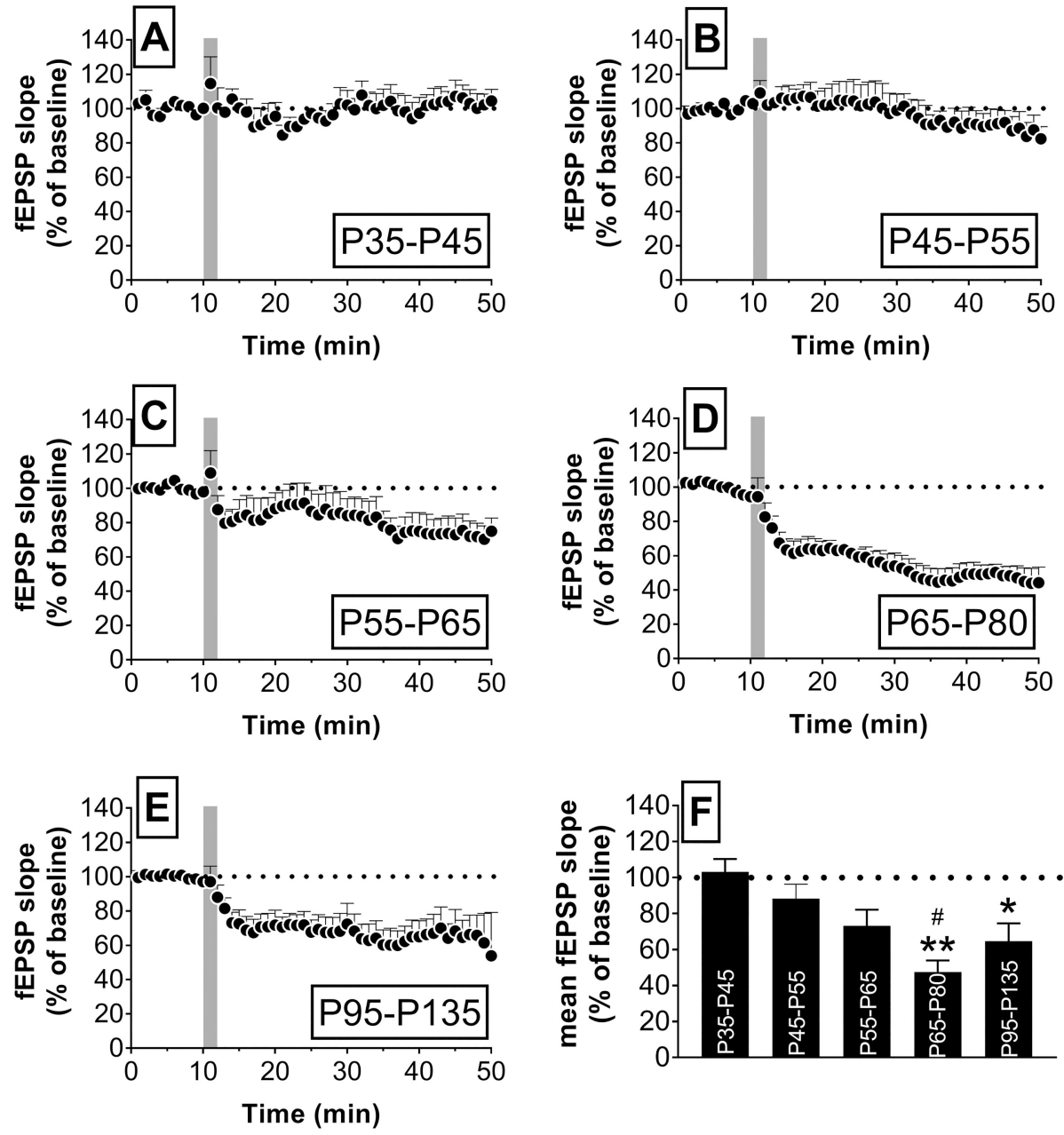

Figure 2.

Age-dependent differences in deep layer PLC plasticity following HFS delivered in superficial layer PLC. (A-E) Effects of HFS delivered in layer 2/3 on the fEPSP slope recorded in layer 5/6 from rats in the indicated age range $(n=5-6$ slices obtained from 4 rats/age group). The shaded vertical bar indicates the HFS period. F. Mean fEPSP response during the 30-40 min period following HFS for each age group. ** $p<0.001$ vs. P35-P45; * $p<0.05$ vs. $\mathrm{P} 35-\mathrm{P} 45 ;{ }^{*} p<0.05$ vs. $\mathrm{P} 45-\mathrm{P} 55$. 
A

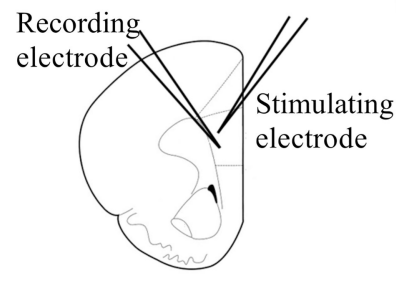

B

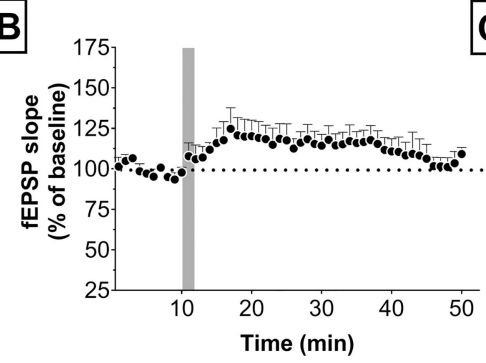

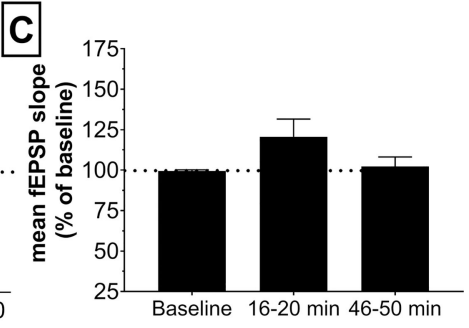

Figure 3.

The effect of intra-laminar HFS on the evoked field potential in the deep layer PLC from young adult rats (P65-P80, $\mathrm{n}=6$ slices from 4 rats). A. Schematic diagram of the location for stimulating and recording electrodes, which were placed in layer 5/6 approximately 400 $450 \mu \mathrm{m}$ apart. B. Effects of HFS (period indicated by shaded vertical bar) on fEPSPs. C. Mean fEPSP response during the 10-min baseline and the relatively early (16-20 $\mathrm{min}$ ) and late (46-50 $\mathrm{min})$ periods following HFS. 
A P35-P45
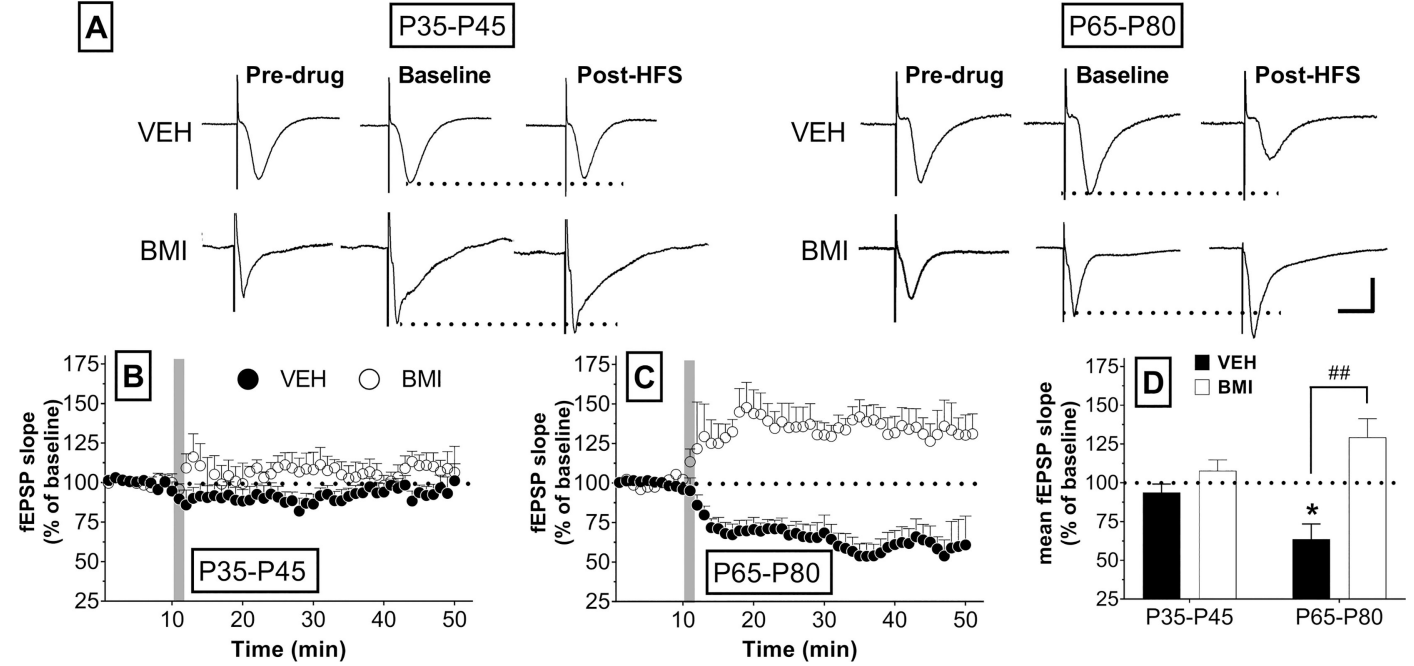

Figure 4.

The effect of $\mathrm{GABA}_{\mathrm{A}}$ antagonist bicuculline (BMI) on HFS-induced plasticity in the PLC of peri-adolescent (P35-P45) and young adult rats (P65-P80). A. Representative traces sampled before (Pre-drug) and after (Baseline) application of $1 \mu \mathrm{M}$ BMI or vehicle (VEH) and following HFS (Post-HFS; calibrarion: $50 \mu \mathrm{V}, 20 \mathrm{~ms}$ ). B-C. Time course of the fEPSP slope before and after HFS (shaded vertical bar) in peri-adolescent and young adult rats ( $\mathrm{n}=5-6$ slices from 3 rats per age group). Slices were exposed to BMI or VEH for the duration of the recording shown. D. Mean fEPSP response from the 30-40 min period post-HFS. ${ }^{*} p<0.05$ vs. P35-P45 VEH; ${ }^{\# \#} p<0.001$ vs. P65-P80 VEH. 

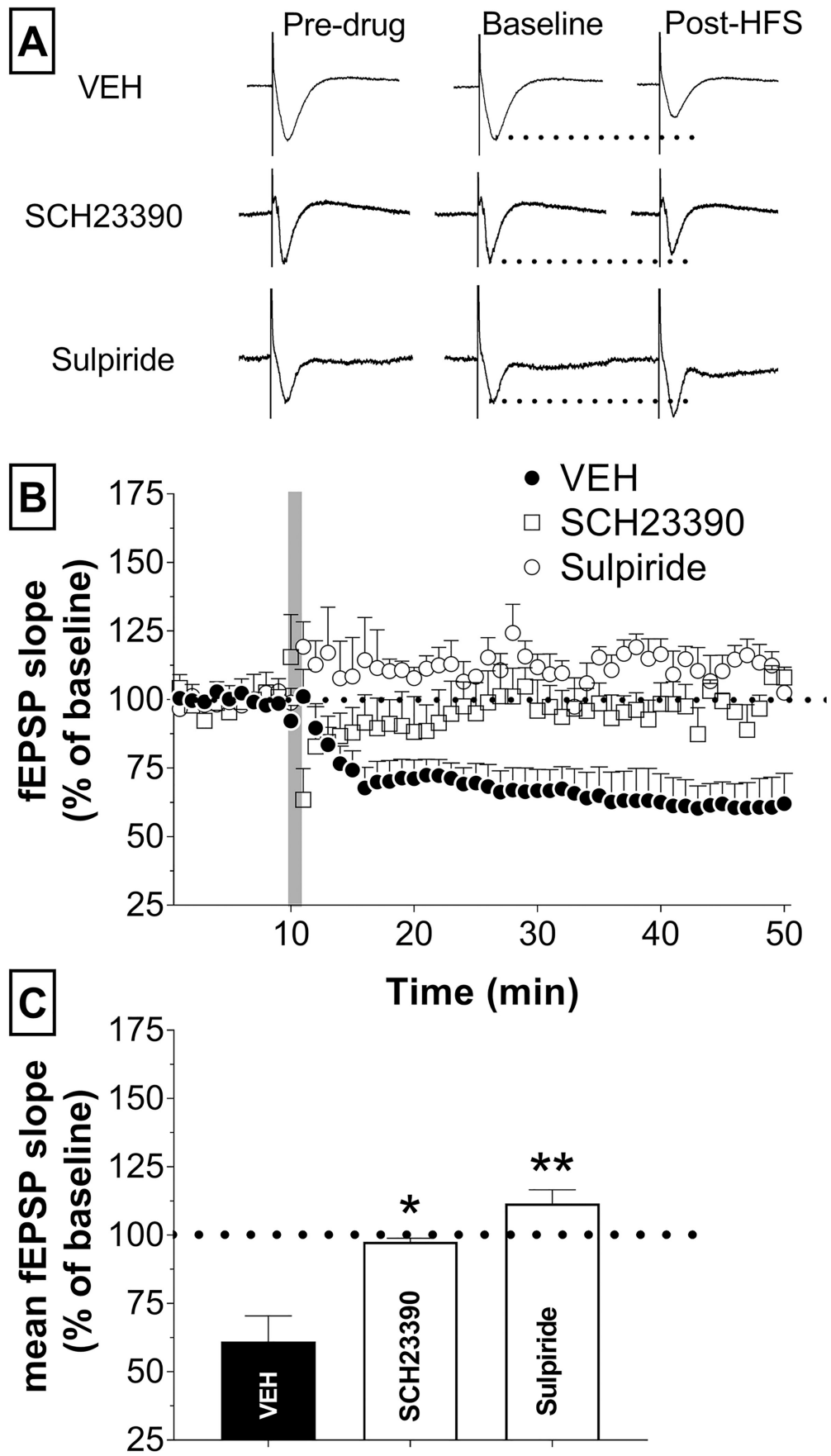

Figure 5.

The role of dopamine $\mathrm{D}_{1}$ and $\mathrm{D}_{2}$ receptors in HFS-induced plasticity in the PLC of young adult rats (P65-P80). A. Representative traces sampled before application of vehicle (VEH), the $\mathrm{D}_{1}$ anagonist $\mathrm{SCH} 23390(10 \mu \mathrm{M})$ or the $\mathrm{D}_{2}$ antagonist sulpiride $(10 \mu \mathrm{M})$, which are labeled Pre-drug, after their application (Baseline), and following HFS (Post-HFS; calibrarion: $50 \mu \mathrm{V}, 20 \mathrm{~ms}$ ). B. Time course of the fEPSP slope before and after HFS (shaded vertical bar) in young adult rats $(n=6$ slices from 3 rats per age group. The time course shown includes the Baseline and Post-HFS periods (i.e., slices were exposed to VEH or a 
dopamine receptor antagonist for the duration of the recording shown). C. Summary of the mean fEPSP response from the $30-40$ min period post-HFS. $* p<0.05 \mathrm{vs} \mathrm{VEH;} * * p<0.001$ vs VEH. 

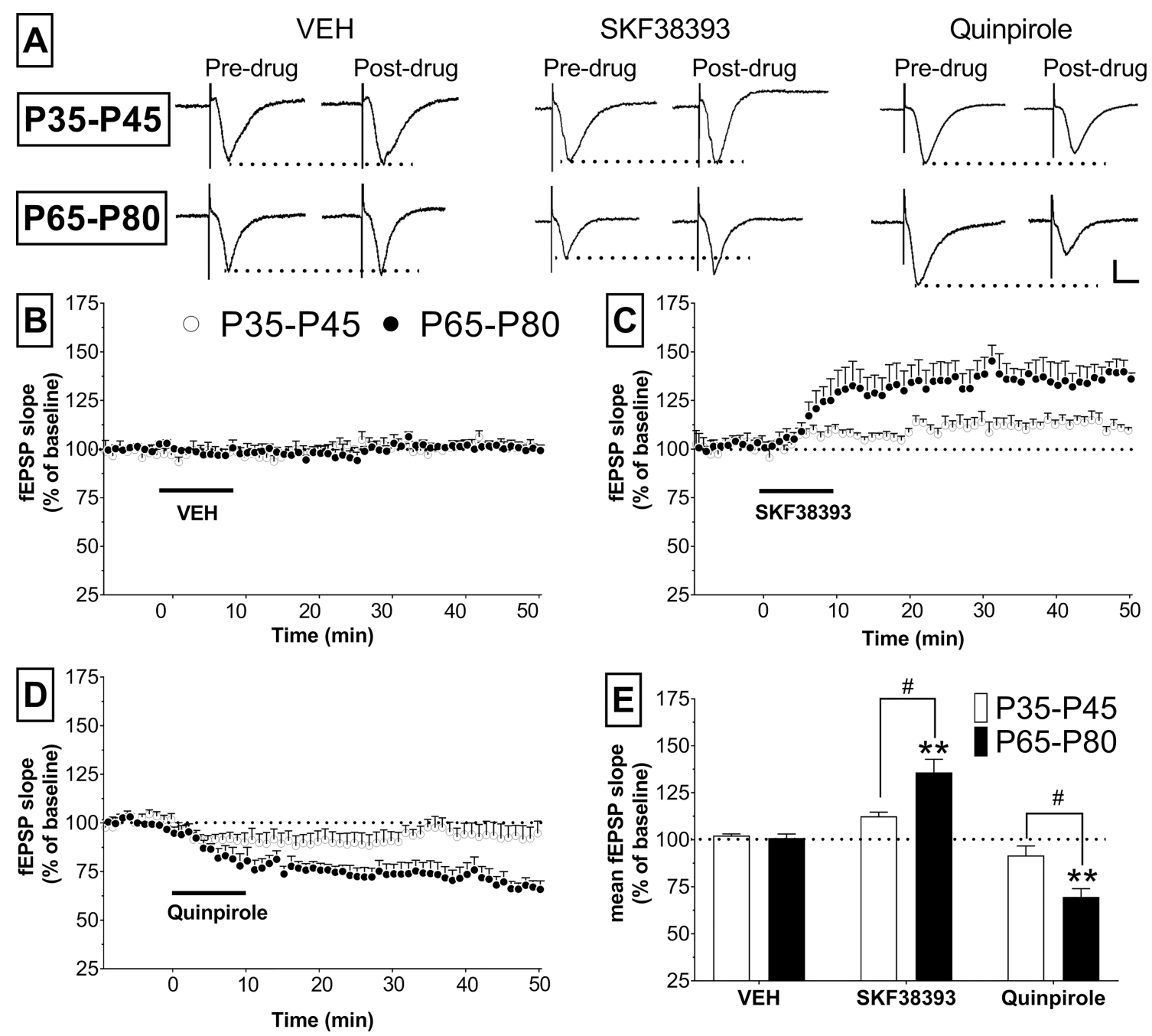

Figure 6.

Age-dependent effect of dopamine $\mathrm{D}_{1}$ and $\mathrm{D}_{2}$ receptors agonists on evoked fEPSP in the PLC of peri-adolescent (P35-P45) and young adult (P65-P80) rats. A. Representative traces sampled before and after application of VEH or drug (Pre-drug and Post-drug, respectively; calibrarion: $50 \mu \mathrm{V}, 20 \mathrm{~ms}$ ). (B-D) Time course of the fEPSP slope before and after application of $\mathrm{VEH}$, the $\mathrm{D}_{1}$ agonist SKF38393 $(10 \mu \mathrm{M})$ or the $\mathrm{D}_{2}$ agonist quipirole $(1 \mu \mathrm{M})$. The 10-min application period is indicated by the horizontal bar $(n=4-6$ slices from 3 rats per group). E. Summary of the mean fEPSP response from the 30-40 min period after VEH or drug application. ${ }^{* *} p<0.001$ vs VEH within age group; ${ }^{\#} p<0.05$ vs P35-P45 within drug condition. 


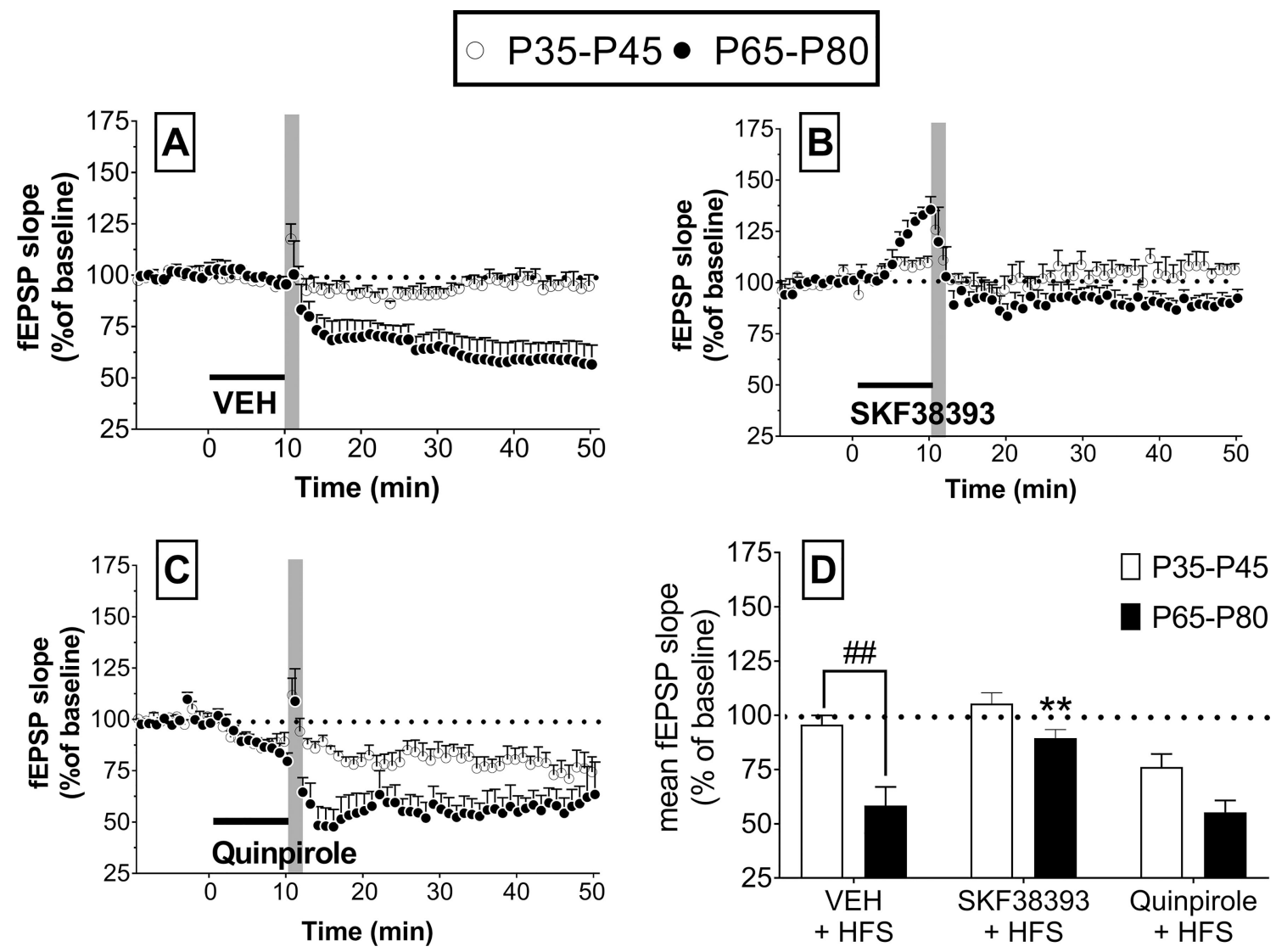

Figure 7.

Age-dependent effect of dopamine $\mathrm{D}_{1}$ and $\mathrm{D}_{2}$ receptors agonist paried with HFS on evoked fEPSP in the PLC ( $n=4-6$ slices from 3 rats per group). (A-C). Time course of the fEPSP slope before and after application of VEH, the $\mathrm{D}_{1}$ agonist SKF38393 $(10 \mu \mathrm{M})$ or the $\mathrm{D}_{2}$ agonist quipirole $(1 \mu \mathrm{M})$. The 10-min application period is indicated by the horizontal bar. The shaded vertical bar indicates the HFS period. D. Summary of the mean fEPSP response from the $30-40 \mathrm{~min}$ period post-HFS. ${ }^{* *} p<0.01$ vs VEH within age group; ${ }^{\# \#} p<0.01$ vs P35-45 within drug condition. 